\title{
CTによる縦隔リンパ節の読影 大きさの測定のばらつきについて
}

\author{
Evaluation of the Accuracy of Measurement of Lymph Node Size \\ by Computed Tomography
}

山田耕三・森 裕二*・鈴木 明*

要旨: 肺癌の縦隔リンパ節転移診断におけるCT診断の精度を高める目的で, 日本肺癌学会 X 線 病型分類委員会では，縦隔リンパ節の読影基準作りを行った。この中で行われた読影実 験の際，読影者によるリンパ節の大きさの測定の“ばらつき”が問題となったので，こ の“ばらつき”について同委員会の協力を得て解析を試みた。読影実験は日常診療の中 で胸部CTの読影に携わっている医師 20 名に, 縦隔のCT像を提示し, 指定した 40 個の縦 隔リンパ節の長径と短径の計80部位を $m m$ 単位で測定させ，各々のリンパ節について大 きさの平均土標準偏差 $(\mathrm{SD})$ と計測不能と判定した場合は, その理由を明記させ検討を加 えた８0部位のリンパ節の中で読影者の測定の“ばらつき”が最も小さかった部位のSD は $1.2 \mathrm{~mm}$, 最も大きかった部位のSDは8.5mmで全測定部位のSDの平均は $2.9 \mathrm{~mm}$ であっ た。この中で\# 1〜\#7の各リンパ節間の部位による“ばらつき”は認めなかったが，リ ンパ節の長径と短径の間では, 短径を用いた計測に“ばらつき”が少なかった。一方, 造影剤使用に関しては, 造影剂の有無でのSDの有意差を認めなかったが, 計測不能とい う回答は明らかに造影剤使用例では少なかった，今後読影者間の“ばらつき”を最小限 にするためには, 造影CTの使用とリンパ節の短径の計測が必要と考えられた.

〔肺癌 33(1) : 37〜 42, 1993〕

Key words : Lung cancer, Mediastinal lymph nodes, Computed tomography

\section{はじめに}

肺癌における縦隔リンパ節転移の診断は，治 療法の選択および, その症例の予後の予測に大 きく関わっている。事実, 縦隔リンパ節転移が 認められた症例の 5 年生存率は手術例の報告で も 30\%を切っているのが現状である ${ }^{1)}$. 現在, 縦 隔リンパ節転移の診断はX $\mathrm{X}$ 線CT (以下CT) 画像 によりなされることが多い.しかしながらCTの 縦隔リンパ節の転移診断の正診率は, 従来の報 告 ${ }^{2), 3)}$ では60 90\%台と低く, かつ施設による差

神奈川県立がんセンター内科第 3 科

* 札幌医科大学第 3 内科
も認められているのが現状である，現在，リン パ節の部位と命名は「肺癌取扱い規約」の規準 に従ってなされている。しかしながら，しばし ばこの基準に対してCT読影上の問題点が指摘 されており4),5), これらがCT画像での正診率の “ばらつき”を生むと考えられている，CTによ る縦隔リンパ節転移診断の精度向上のためには, まずCTでの縦隔リンパ節の部位と命名の確立 された基準作りが必要となるが, 日本肺癌学会 のX線病型分類委員会でこの基準作りに着手し た。同委員会では『X線CTによるN因子検討部 会』を発足させ，CTによる縦隔りンパ節命名と 
部位についての検討を行った。この中の読影実 験の結果から, 従来の取扱い規約の基準のみで は, CT上のリンパ節の命名と大きさの計測に読 影者間での“ばらつき”が生ずることが判明し た。

リンパ節の命名については, すでに委員会報 告(案)が出されている. 一方, 現状の画像によ るリンパ節の転移の判定基準は, 個々のリンパ 節の大きさから判定するとされており, 本来的 には読影者間に大きなリンパ節の測定誤差がな いことが前提である。しかしながら，個々の読 影者によるリンパ節計測の“ばらつき”が生ず ることが, 今回の読影実験で改めて確認された。 従来, CT画像での読影者間の測定の測定誤差に ついての検討は殆どなされていないが, CTのリ ンパ節診断精度の向上には欠かせない研究と考 えられる。本稿では今回の日本肺癌学会 X線病 型分類委員会における読影実験での, CT像のリ ンパ節を計測する読影者の間に，どの程度の測 定誤差が生じていたか，また今後どの様に対処 すべきかを検討したので報告する.

\section{対象・方法}

縦隔条件のCT像 (スケール入り)のプリント 写真を作製し，描出されているリンパ節の中で, 無作為に選んだリンパ節を矢印で示し(40部 位：肺癌取扱い規約の縦隔リンパ節\# 1 から\# 7 までの各部位；\# 1, \# 2 は各 5 個ずつ, \# 3 7 は 6 個ずつの計 40 リンパ節で，大きさとしては 10〜30mm径のリンパ節を選んだ), その長径と 短径を各読影者に計測させ, mm単位で読影シ 一トに記入させた。また計測不能の場合にはそ の理由を読影シートに記載してもらった．検討 した項目は 1）各リンパ節の計測部位の標準偏 差(SD)の大きさ．2）各リンパ節の測定值の平 均値とSDの相関. 3) 同一リンパ節の長径のSD と短径のSDの差.4）計測不能とした理由. 5) 全読影医が計測可能と判断したリンパ節のSD と読影医が一人でも計測不能と回答したリンパ 節のSDとの比較。の 5 項目であった。使用した CT装置は東芝製TCT-900Sまたは，TCT-60A でスライス厚 $10 \mathrm{~mm}$ で撮影し, 描出条件はwin-
Fig. 1. Histogram of S.D.

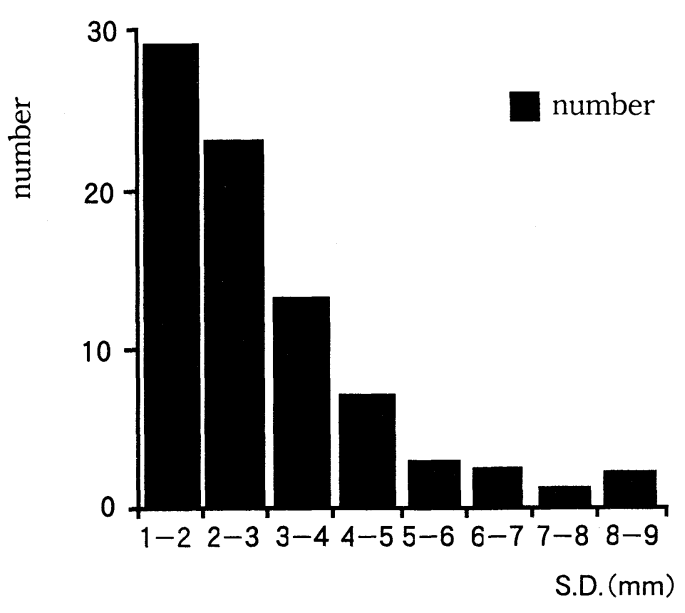

dow level : 50 H.U., window width : 300 H.U. に統一した。造影剤使用例は経静脈的に $100 \mathrm{cc} の$ 水容性造影剤を $0.6 \mathrm{cc} /$ 秒で注入し, 注入後 30 秒 後より撮影した。選んだリンパ節の中で20部位 は造影CT，20部位は単純CTの症例であった。 読影実験に参加した読影者は日常診療で, 各施 設の胸部CTの読影に携わっている全国の12施 設の医師 20 名 (放射線科医 9 名, 内科医 8 名, 外 科医 3 名）であった. なお相関係数の算出はピア ソンの相関係数を, $\mathrm{SD}$ 差の検定は $\mathrm{t}$ 検定を用 いた。

\section{結 果}

1）各計測部位の標準偏差の大きさ (Fig. 1)

40 リンパ節の長径, 短径合わせて 80 部位の計 測の中で，大きさの測定の“ばらつき”が最も 小さかった部位のSDは1.2mmであった。一方， 測定の“ばらつき”が最も大きかった部位のSD は8.5mmで, 全測定部位のSDの平均は $2.9 \mathrm{~mm}$ であった。なお各リンパ説の部位別のSDの平均 は\# $1: 2.1 \mathrm{~mm}$, \#2:2.9mm, \#3:3.5mm, \# $4: 3.8 \mathrm{~mm}$, \# $5: 2.6 \mathrm{~mm}$, \# $6: 2.3 \mathrm{~mm}$, \# $7: 2.9 \mathrm{~mm}$ であり, \# 1 から\# 7 の各リンパ節間 でのSDに関しては有意差を認めなかった。また この中で造影剤使用の有無に関しては, 使用 $(+)$ のDの平均は $2.6 \mathrm{~mm}$, 使用 $(-)$ の $\mathrm{SD}$ の平 均は $3.2 \mathrm{~mm}$ であり, これも統計学的な有意差は 
Fig. 2. Correlation between mean and S.D.

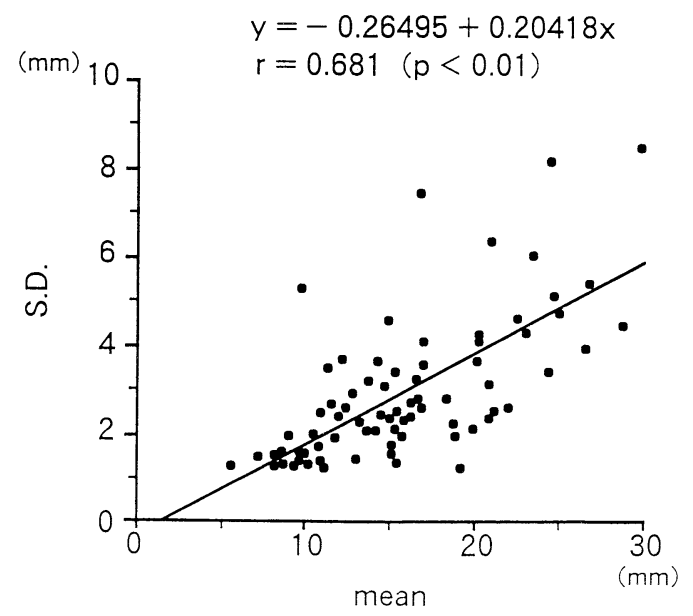

認めなかった。

\section{2）各計測部位の計測値の平均値とSDの相関}

(Fig. 2)

各々の部位の測定値の平均值と SDとの間に はr $=0.681(\mathrm{p}<0.01)$ で有意の正の相関性が認 められ，大きなリンパ節ほど径の計測の“ばら つき”が大きくなる傾向が認められた。

3）同一リンパ節の長径のSDと短径のSDの差

リンパ節の径の計測の“ばらつき”を個々の リンパ節の長径と短径で見た場合, 長径の “ば らつき”の方が短径のそれより大きかった(長径

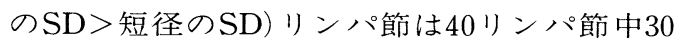
リンパ節で認められた。一方, 短径の “ばらつ き”の方が長径のそれより大きかった(長径の

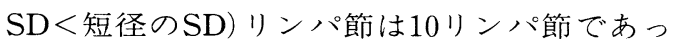
た. 前者の $\mathrm{SD}$ 差の平均值は $1.2 \mathrm{~mm}$ で, 後者の

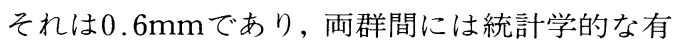
意差を認めた $(\mathrm{p}<0.01)$. 長径の $\mathrm{SD}>$ 短径の $\mathrm{SD}$ であったリンパ節を retrospectiveに解析して みると, 長径側のいずれかに隣接の藏器が接し

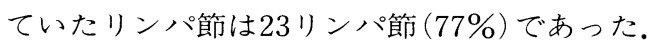
一方, 長径の $\mathrm{SD}$ <短径のSDであったリンパ節 では, 長径側のいずれかに隣接藏器が接してい たリンパ節は 2 リンパ節 (20\%)のみであった。

\section{4）計測不能とした理由}

20 名の読影者の 40 リンパ節の計測の回答 1600
Table 1. Difference of S.D. between the size which all observers could measure and the size not measured by some observers.

\begin{tabular}{cccc}
\hline \multirow{2}{*}{ group } & number & \multicolumn{2}{c}{ S.D. } \\
\cline { 3 - 4 } & & mean & S.E. \\
\hline A & 57 & 2.38 & 0.14 \\
$\mathrm{~B}$ & 23 & 4.02 & 0.43 \\
\hline \multicolumn{3}{c}{}
\end{tabular}

group $\mathrm{A}$ : the size of lymph nodes concerning which consensus was obtained among all observers group B : the size of lymph nodes concerning which consensus was not obtained among all observers

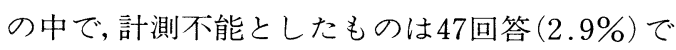
あった。「計測不能」と 1 人の読影医でも回答の あったリンパ節は右の\# 1 が 1 個, 右の\# 2 が 2 個, 左の\# 2 が 1 個, \# 3 が 4 個, 右の\# 4 が 2 個, 左の\# 4 が 3 個, \# 5 が 4 個, \# 6 が 3 個, \# 7 が 3 個の計 23 リンハ節であった. 計測不能と した理由の内訳はリンパ節と縦隔内の血管との 境界が不明瞭 $42 \%$, 食道との境界が不明瞭 13 $\%$, CTのartifact 13\%, 隣接するリンパ節との 境界が不明瞭 $9 \%$, 気管または気管支との境界 が不明瞭 $4 \%$, 明確な理由の記載がないもの 19 \%であった。

5）全読影医が計測できたリンパ節のSDと, 一人でも計測不能の回答があったリンパ節の SDの比較 (Table 1)

リンパ節の全計測80部位を, $\mathrm{A}$ 群：全読影医 が測定可能であった計測部位, B群：一人でも 「計測不能」と回答した計測部位の 2 群に分類 した。この 2 群間には統計学的に有意差を認め $(\mathrm{p}<0.01)$ ，一人でも「計測不能」と判定した部 位と比較して, 全読影医が計測可能と判断した 部位は読影医間の計測の “ばらつき”が少なか つた。

\section{考 察}

肺癌のリンパ節転移の診断は, CT画像により なされることが多い.CT画像において, 正常の リンパ節と転移を認めるリンパ節との間にdensityの差はなく, 現状では転移の有無の判断は 
リンパ節の大きさによるところが多い. 従来, リンパ節の大きさの評価方法としては, リンパ 節の長径または短径を用いての報告が多く，転 移の判定に様々なリンパ節径が提唱されてい る2),3). しかしながらCTでの正診率は，たかだか 60〜90\%であり，MRIの報告6)でも同様である. これは開胸時の所見でリンパ節が大きく腫大し ていても切除病理所見では転移像はなく反応性 の腫大像のみのこともあり，また逆に開胸時に は正常な大きさのリンパ節でも組織学的には癌 の転移像が広範囲に認められる症例7の存在か らも明らかである。したがって，診断精度の向 上には縦隔鏡の併用が最も好ましいとされてい るが8), 全身麻酔下で行う必要があり手技的に 日常の検查として取り入れるには難点がある。 また超音波内視鏡を用いたリンパ節の内部構造 からの転移診断の報告もあるが9), まだ確立さ れた診断基準は得られていない，以上より現状 ではCTによる診断が最も簡便であると考えら れ，その精度にある程度の幅を持たせてもCT画 像上の個々のリンパ節の大きさで判定せざるを 得ない。

CT画像でリンパ節転移の診断を一般化する 場合, CT画像上での縦隔リンパ節の部位と命名 の基準の確立を行い, 部位と命名に関して施設 間での “ばらつき”をなくすことが不可欠かつ 先決である。これはすでに日本肺癌学会X線病 型分類委員会の『X線CTによるN因子検討部 会』で約 2 年間に渡って検討された ${ }^{10)}$. 次に, 肺 癌のリンパ節転移診断をCT画像上のリンパ節 の径で判定するには, 読影者間での測定誤差が ないことが前提となるが，これに関しては今ま で殆ど検討されていない.今回，2 年間に行わ れた読影実験の各読影者間の縦隔リンパ節測定 誤差を retrospectiveに解析し，CTのリンパ節 転移診断の精度向上のために今後どの様な研究 を行うべきかを検討した。

リンパ節の大きさとその計測の“ばらつき” の関係に関しては, リンパ節径が大きいほど計 測の “ばらつき”が大きくなる傾向が認められ た。これは今回のCT画像を retrospectiveに解 析してみると, 問題となった大きなリンパ節は
縦隔内の大血管, 食道, 気管などの隣接臟器と 近接する頻度が高くなっていた。このためリン パ節の辺縁の設定が困難となりやすく, リンパ 節径の測定の際に個人差が生じたと考えられた。 従来の報告では，気管分岐部リンパ節，傍食道 リンパ節，肺勒带リンパ節などの気管分岐部， 食道, 左房に接した領域に限って, CTでのリン パ節の検出が困難とされていたが11), ぞの領域 のリンパ節でも腫大すれば隣接臓器と接するこ とになり，辺縁の設定に個人差が出現し，計測 に“ばらつき”が出現すると考えられる。この 事実は従来の報告では一度も検討されてなく， 大きさに頼っている現状のリンパ節転移診断に おいては，注意すべき点と考えられた。

リンパ節の計測部位に関しては，リンパ節の 長径と短径の計測の比較を行ったが, 長径の方 が短径よりも読影者間の“ばらつき”が大きく なる傾向が見られた。これは長径側に隣接臟器 がくる傾向があり，測定の際にリンパ節の辺縁 の設定に個人差が出現した一因と考えられた. 計測部位の設定はリンパ節の一方向 ${ }^{121}$, 二方 向 ${ }^{13)}$, 長径と短径の相乗平均 ${ }^{14)}$, 面積 ${ }^{15)}$ な゙いろ いろな方法が報告されているが，一般的には最 大径一方向を採用しているものが多いようであ る。しかしながら測定誤差を最小限にするため には，今回の結果からはリンパ節の短径を測定 部位として採用すべきと思われる。

計測不能とされたリンパ節を検討してみると， その約 $50 \%$ がリンパ節と縦隔内の血管との境界 が不鮮明のため, 読影不能と判断されていた。 この不鮮明とされたCT画像は造影剤が使用さ れていないか,または造影効果が不十分なCT画 像であり，CTの機種による差は認めなかった。 従来, CTでのリンパ節の腫大の診断は, 水溶性 造影剂投与による影響はないとの報告 ${ }^{16)}$ がされ ている.今回の検討では造影剂 $(+)$ のDの平均 は2.6mm, (一)でのSDの平均は $3.2 \mathrm{~mm}$ で両者 間に統計学的な差を認めなかった。しかしなが ら「計測不能」との回答は造影剂 $($ 一) 例に多く, 正確なリンパ節の径の計測にはやはり造影CT での計測が必要であると考えられた。しかし食 道，気管・気管支，隣接するリンパ節との境界 
に関しては造影CTと造影剤なしのCTでは，差 は認めなかった。食道, 気管などに対してはス ライス厚を薄くすることにより，区別を明瞭に できるとの報告もあるが17)，今回はスライス厚 に関しては検討できておらず，今後の課題と考 えられる。

リンパ節の部位別の検討では，今回検討した \# 1 から\# 7 の間では測定誤差の差を認めなかっ た。しかし読影者の一人でも「計測不能」と判 定した部位と全読影者が「計測可能」とした部 位を比較してみると, 有意差をもって後者の読 影者間の計測の“ばらつき”が少なかった。リ ンパ節の部位別にみた腫大の診断基準に関して の報告では, 部位によりその診断基準を変える べきであるとの報告もあるが4)，リンパ節径の 計測誤差に関しては，部位別による違いは認め ず，各々の部位別の診断基準に関しては今回は 切除病理との比較を行わなかったため検討でき なかった。

今回の検討の結果から, CT画像を用いての縦
隔リンパ節径の計測に, 読影者間での思いも掛 けぬ“ばらつき”が明らかとなった。今後正確 なリンパ節の計測には造影CTを用い,リンパ節 の短径を計測する必要があると考えられる.CT 診断の精度に関しては, 今回の読影実験ではCT 上のリンパ節の径とその組織学的診断の関連を, 切除例が少ないため言及できなかった。今後, CTを用いた縦隔りンパ節診断の確立のために は, 日本肺癌学会の X線病型分類委員会で新し く定めた縦隔リンパ節部位のCT読影基準 ${ }^{18)} に$ そっての, CT診断とその切除病理との比較を行 った上で, 縦隔リンパ節の部位別の診断基準を 確立する必要があると思われる。

本論文は日本肺癌学会 $\mathrm{X}$ 線病型分類委員会の各委 員および関係施設諸氏との共同研究であり深謝致しま す。また本研究に対して終始ご助言いただきました国立 がんセンター土屋了介先生, 放射線医学総合研究所福久 健二郎先生に深謝致します。

文

1）西山祥行，高橋健郎，西村光世, 他：p-N2III期 肺癌切除例の検討. 肺癌 31(2) : 183-191, 1991.

2）森 雅樹, 森 裕二, 山岸雅彦, 他：CTによる 肺癌の縦隔リンパ節腫大・転移の診断。肺癌 $28: 457-464,1988$.

3) Quint LE, Glazer GM, Orringer MB, et al : Mediastinal lymph node detection and sizing at CT and autopsy. AJR 147:469-472, 1986.

4）松原敏樹, 木下 巌, 中川 健, 他: 大きさか らみた肺癌上絴隔転移のCT診断一特に適切な 診断の闇值について一。肺癌 $26: 769-777$, 1986.

5）浅井龍二, 河野通雄, 村尾豪之, 他: 肺門, 縦 隔リンパ節のCT mapping とその問題点一特に 肺癌取扱い規約との対比検討一. 臨放 30 ： 1523-1528, 1985.

6）岩井直路，山口 豊：MRIにおける肺癌所属り ンパ節転移の至適診断基準に関するROC曲線 による検討．肺癌 31：835-842， 1991.

7）前原康延, 松本満臣, 野崎美和子, 他：原発性 肺癌の術前臨床病期分類におけるCTの有用性 についての評価。肺癌 $25: 581-588,1985$.

8）安光 勉, 大嶋仙哉, 中野 昇, 他: 手術適応 が考えられた肺癌症例に対する連続600例の縦 隔鏡検査成績; 肺がん集学的治療の最前線, 癌 と化学療法社, 東京, P10 1989.

9）李 典利, 井上清俊, 山本良二, 他：肺癌N因 子診断に打ける超音波内視鏡(EUS)の有用性. 肺癌 $31: 7651991$.

10）森 裕二，山田耕三，鈴木 明，他：縦隔リン パ節のCT診断における部位命名の一致性に関 する検討。肺癌, 投稿中

11）山下長司郎, 坪田紀明, 青垣内龍太, 他：肺癌 における縦隔リンパ節転移のCT診断の評価. 肺癌 $27 ： 149-1541987$.

12) Baron RL, Levitt RG, Sagel SS, et al: Computed tomography in the preoperative evaluation of bronchogenic carcinoma. Radiology 145：727-732, 1982.

13）森 清志, 江口研二, 森山紀之, 他：肺癌の術 
前評価における胸部CT と胸部 X 線診断。肺癌 $26: 381-3901986$.

14）松原敏樹, 堀 雅晴, 中川 健, 他：肺癌縦隔 リンパ節転移のCT診断. 臨床外科 $38 ： 1203-$ $1210,1983$.

15) Glazer GM, Orringer MB, Gross BH, et al. : The mediastinum in non-small cell lung cancer; CT-surgical correlation. AJR 142 : 1101-1105, 1984.

16）森 雅樹, 森 拓二, 井上祐二, 他：CTスキャ
ンによる縦隔リンパ節腫大の診断一肺癌手術 例における検討一。肺癌 $24: 569,1984$.

17）吉田祥二, 前田知穗, 西岡正俊, 他：縦隔・肺 門リンパ節病変におけるthin slice $(5 \mathrm{~mm})$ target CT scanの有用性. 日画像医会誌 $5: 1179$ $-1185,1986$.

18）縦隔リンパ節部位のCT読影基準一案一につい ての報告. 日本肺癌学会 X線病型分類委員会, 委員会報告，1992.

(原稿受付 1992 年 6 月 18 日 /採択 1992 年 8 月 19 日)

\title{
Evaluation of the Accuracy of Measurement of Lymph Node Size by Computed Tomography
}

\author{
Kouzo Yamada , Yuji Mori $^{2}$ and Akira Suzuki ${ }^{2}$
}

\author{
Department of Thoracic Disease ${ }^{1}$, Kanagawa Cancer Center \\ Department of Internal Medicine (Section 3) ${ }^{2}$, Sapporo Medical College
}

Computed tomography (CT) has now assumed a major role in the evaluation of the mediastinal lymph nodes. However several potential problems exist in the use of $\mathrm{CT}$ for the evaluation of mediastinal lymph nodal metastases from lung cancer; CT criteria for nodal involvement by tumor rely on nodal size. Accurate methods of measuring the size of lymph nodes have yet been established.

We investigated the size of 40 mediastinal nodes which were measured on CT by 20 independent blind observers. The mean standard deviation of nodal size was $2.9 \mathrm{~mm}$ (range : $1.2-8.5 \mathrm{~mm}$ ). The mean standard deviation of nodal size using the shortest dimension as indicator was smaller than that of nodal size using the largest dimension $(\mathrm{p}<0.01)$. Neither the site of mediastinal lymph node or the use of contrast enhanced CT images had any significant difference in the standard deviation of nodal size. However the use of contrast enhanced CT images slightly inproved the accuracy of measurement of nodal size than by the plain CT images.

In conclusion, we need to adopt the using shortest dimension of lymph nodes as an indicator and contrast enhanced CT images for diagnosis of mediastinal lymph node metastases to improve diagnostic accuracy. 